\title{
THE ELECTION OF HUGO HAASE TO THE CO-CHAIRMANSHIP OF THE SPD AND THE CRISIS OF PRE-WAR GERMAN SOCIAL DEMOCRACY
}

The election of Hugo Haase to the Co-Chairmanship of the German Social Democratic Party (SPD) in 1911 was an event of immense importance for the future of German Social Democracy. It was Haase who served as the principal spokesman of the opposition to the cooperationist policies of the majority during World War I. It was he who led that opposition out of the SPD in 1917. After the war, as cochairman both of the revolutionary government and of the Independent Social Democratic Party, he helped to insure that the German movement would remain permanently divided.

Despite the obvious significance of Haase's election, the circumstances surrounding it have received surprisingly little attention from historians. This can be at least partially explained by the fact that it aroused relatively little public debate at the time. Yet a careful examination of the available evidence reveals that it was by no means as simple a matter as it has usually been portrayed. In fact, Haase agreed to run for the office only after lengthy discussion and not a little soul searching. Moreover, the nature and tone of these preliminary negotiations shed additional light both on the character of the leading participants and on the problems facing the SPD during the crucial final years before the war.

Haase was by no means the only or even the most obvious candidate to replace Paul Singer, who died on January 31, 1911. In contrast to Singer, who had been a figure of national importance since the early years of Bismarck's anti-socialist law, Haase was in 1911, at the age of forty-seven, still a relative newcomer to the upper echelons of the party leadership and a virtual unknown to the membership at large. On the other hand, a brief examination of the backgrounds of the two men reveals a number of interesting similarities which undoubtedly help to explain Haase's candidacy. Like Singer, Haase was the product of a lower middle class Jewish family, and like him he had achieved considerable success in the world of the bourgeoisie. Both men devoted a considerable proportion of the wealth they thus acquired to party and other philanthropic activities without, however, giving up their 
essentially bourgeois way of life. ${ }^{1}$ Most important, Haase proved himself to be, like Singer, both a strong party man and a consistent supporter of the "orthodox" point of view in the theoretical debates which played such a large part in the life of the pre-war SPD.

Haase's comparative obscurity can be at least partially explained by the fact that while Singer began his official career as a member of the Berlin City Council, Haase received his initiation into public life when he was elected, in 1894, to the City Council of distant Königsberg. ${ }^{2}$ It was not long, however, before Haase was provided with an entrée onto the national stage. In 1897 Karl Schultze, who had represented Königsberg in the Reichstag since the Social Democrats first conquered the seat in 1890, died, and the local party leaders chose Haase to replace him. Yet, although he retained his seat in the Reichstag until 1907,3 the young attorney from East Prussia found himself relegated to a relatively minor role. $\mathrm{He}$ is rarely mentioned in the minutes of the Social Democratic Reichstag delegation meetings, ${ }^{4}$ and his rather

I Singer lost his father at the age of four ands thus grew up without enjoying many of the amenities of a middle class homelife. He was forced to become an apprentice in a drapers shop at the age of fourteen. At the age of twenty-five, however, he and his brother established their own shop and soon amassed a considerable fortune. For a brief biographical sketch, see Franz Mehring, "Paul Singer", in: Die Neue Zeit, XXIX, 1 (1910-11), pp. 649ff. Haase was more fortunate in his youth. The eldest son of a shoemaker turned flax merchant, he was able to attend the Gymnasium at Rastenburg and then study law at Königsberg. Ernst Haase, Hugo Haase (Berlin: J. J. Ottens, 1929), pp.1ff. Once admitted to the bar he devoted a considerable amount of time to defending the local party newspaper and individual party members without compensation. At the same time, however, he was able to establish a flourishing civil practice which allowed him both to maintain a comfortable home and to contribute substantially to the local party. Interview with Hans Haase (Hugo Haase's nephew) and telephone interview with Kurt Boenheim (later Hugo Haase's legal partner), August 1965. See also Karl Marchionini, “Erinnerungen an Hugo Haase", in: Leipziger Volkszeitung, No 251, November 7, 1919. J. P.Nettl appears, therefore, to have been unjustified in listing Haase as one of those socialist lawyers whose work was "wholly confined to the defence of socialist interests" in his very interesting article, "The German Social Democratic Party 1890-1914 as a Political Model", in: Past and Present, No 30 (1965), pp. 68-69. It certainly did not, as Nettl suggests, constitute a "socialist vested interest". 2 It was, however, not unusual for a successful provincial party leader to rise to high party office. Nettl, "The German Social Democratic Party ....", p. 77. 3 Haase's defeat in 1907 did not represent a major personal setback inasmuch as his fate was shared by a large number of his colleagues. The Social Democratic delegation was reduced from seventy-nine to forty-three members. Haase was again elected to the Reichstag in 1912.

- See the excellent edition of these minutes recently published by the Kommission für Geschichte des Parlamentarismus und der politischen Parteien. Erich Matthias and Eberhard Pikart, eds, Die Reichstagsfraktion der deutschen Sozialdemokratie 1898 bis 1918 (Düsseldorf: Droste, 1966). 
infrequent speeches on the floor of the Reichstag were largely confined to matters specifically related to his area of special competence, legal affairs.

The minutes of national party congresses also provide, at least during the early years, scant evidence that Haase was destined to become a figure of national prominence. Although he attended most of these annual meetings of the party's highest governing body after 1896, he rarely played an important role on the convention floor. His first major speech, delivered at the convention of 1906, was, to be sure, generally well received, but it was devoted to the relatively noncontroversial subject of class based discrimination in contemporary legal practices. ${ }^{1}$ It was not until the Magdeburg convention of 1910 , just a few months before Singer's death, that he began to emerge clearly as the potential leader of a major faction in the party.

The principal question at issue in Magdeburg concerned a new revolt by the reformist-dominated southerners against the long-established and recently reconfirmed party prohibition against voting for the budget of a capitalist state. In August of that year the Social Democratic delegation in the Baden Landtag once again challenged this proscription by voting for their state's budget. Haase was a member of the "commission of seven" that was organized by Wilhelm Dittmann before the convention to direct the counterattack against the rebels. ${ }^{2}$ When the explosive issue reached the convention floor, it was Haase who led the successful campaign for a new and more vigorous condemnation of the southerners' breach of discipline. ${ }^{3}$

1 Protokoll über die Verhandlungen des Parteitages der Sozialdemokratischen Partei Deutschlands, 1906, pp. 360ff. It should be noted, at least in passing, that Haase played a significant role at the 1908 congress where he served as chairman of a committee set up to work out a compromise on the explosive issue of how the party should deal with the growing socialist youth movement. Protokoll ..... 1908, pp. 226, 450f. See also Carl Schorske, German Social Democracy 1905-1917 (New York: John Wiley and Sons, 1965), pp. 106ff.

2 The commission was set up by delegates attending the Copenhagen meeting of the International late in August. It arranged for some two hundred delegates to meet in Magdeburg immediately prior to the convention. This larger group then assigned to the commission the task of directing the counterattack on the budget issue. Wilhelm Dittmann, "Erinnerungen" (unpublished manuscript, typed transcription by Georg Kotowski in the Internationaal Instituut voor Sociale Geschiedenis, Amsterdam), pp. 273ff. It is interesting to note in this context that four members of the commission of seven later became leading figures in the Independent Social Democratic Party. In addition to Haase himself, these included Dittmann, Kurt Rosenfeld and Richard Lipinski.

3 Protokoll . . . , 1910, pp. 288ff. It should be noted that Haase and his friends were for a time willing to compromise on the issue. Under pressure from Bebel, they agreed to withdraw their stiffening amendment to the executive committee's 
At the time of Singer's death, therefore, Haase had only very recently begun to play the kind of public role one might expect of a potential national party leader. His leadership of the left-center majority at the Magdeburg convention undoubtedly set the stage for his candidacy. Yet one must look behind the scenes to discover exactly why and how that candidacy finally in fact materialized.

Singer's death was, in the first place, just part of a larger leadership crisis which had been developing in the SPD for several years. Singer had been ailing for some time, as had his co-chairman, August Bebel, and another older colleague on the executive committee, Karl Gerisch. Moreover, the rapid growth of the party had required the introduction of new methods, the establishment of a tightly organized bureaucracy and, of course, the recruitment of new men to direct the rapidly expanding party apparatus. Thus, the old established leaders appeared to be losing out to a new breed of "organization men" who were widely viewed as little more than highly competent bureaucrats who by their very success threatened to stifle completely the revolutionary fervor of the movement. Although many of these new men had not yet made common cause with the revisionists, they were nevertheless suspect to those who remained tied to the traditional theoretical commitment to an eventual overthrow of existing society.

There was, therefore, considerable sentiment even before Singer's death for the addition of members to the executive who would more clearly represent the traditional philosophy of the party. This feeling was further stimulated by the success of the radicals at the Magdeburg convention. ${ }^{1}$ The death of Singer merely provided an opportunity for this sentiment to congeal and focus on a specific course of action. And the fact that it was Singer, considered even more than Bebel the

resolution on condition that the party chairman would read a formal statement, worked out by Haase and Bebel, declaring that the executive committee agreed with the intent of the sponsors of the amendment and would interpret its own resolution in this light. Ibid., p. 360; Dittmann, pp. $287 \mathrm{ff}$. This settlement was, however, shattered by the provocative response of the southerners. When Ludwig Frank taunted Haase and his friends for their "retreat" and declared that whether he and his colleagues voted for future budgets would depend entirely upon circumstances, Haase called for an immediate adjournment. Protokoll ...., 1910, pp. 366ff. When the meeting was reconvened, a new amendment was presented making the statement worked out by Haase and Bebel a formal resolution of the convention. When Haase and his associates insisted that this resolution be voted upon immediately a large number of the dissidents left the hall. Haase then made a short speech decrying Frank's remarks as "a slap in the face of the great majority of the convention ....", whereupon the amendment was passed by a substantial margin. Ibid., pp. $372 f f$. 1 Dittmann, for instance, reported that he was urged at that time by many of the radical leaders to seek a place on the executive committee. Dittmann, p. 297. 
bulwark of the old radicalism, who had passed away made it even more imperative for those who stood generally on the left, encouraged by their recent success, to demand that his replacement be someone who enjoyed their confidence.

The selection of an appropriate candidate, however, proved to be no easy task. The party simply did not have any more figures like Bebel, who clearly towered over other potential leaders. This situation was partly a result of the recent political fractionalization of the party. Ludwig Frank, for instance, who has often been compared with Ferdinand Lassalle, ${ }^{1}$ was absolutely unacceptable because of his close association with the minority revisionist wing. On the other hand, the extreme left had no figures of sufficient stature to overcome the increasing isolation of that group. This fact would be made more than ever apparent at the coming convention when Bebel would make a final and decisive break with Rosa Luxemburg, intellectually the most impressive leader among the left radicals. ${ }^{2}$

In this situation the logical place to look for a national leader was, of course, the so-called "center", and the most highly respected centrist leaders were generally to be found within the executive committee. Several of the members of that body, however, were, as we have noted, either too old or too ill to qualify. Among the younger members, Friedrich Ebert did show considerable promise, especially as a possible compromise candidate. On decisive questions he had usually voted with the "principled" left against the revisionists, yet as a competent administrator and practical politician he had considerable appeal for the right wingers. They sensed that he basically sympathized with their approach. Many on the left, however, undoubtedly sensed this too. He was, after all, a member of the new bureaucracy who tended to be more concerned about immediate practical problems than about purity of doctrine. Although apparently seriously considered, Ebert himself recognized that the time was not ripe and declined to seek the position. ${ }^{3}$

It was under these circumstances that Haase's candidacy developed and gradually assumed for many leaders the proportions of a virtual necessity. The suggestion that Haase should be made a member of the executive had been made at least as early as 1909. In one of his letters to Haase in that year, Karl Kautsky asked his friend if there was any

1 Jacob Toury, Die politischen Orientierungen der Juden in Deutschland (Tübingen: J.C.B. Mohr, 1966), p. 232.

J J.P. Nettl, Rosa Luxemburg (London: Oxford University Press, 1966), I, pp. 445ff.

3 Protokoll . . . , 1911, pp. $371 \mathrm{f}$. 
possibility of his moving to Berlin. "I recognize very well", he wrote, "that it would involve a great financial sacrifice on your part, but if you were active at the center of the movement you could now accomplish things of world-historical significance .... Tell me yourself who else could replace Bebel in the leadership of the party."1 Haase, however, did not share Kautsky's confidence. "Your proposal that I should become a candidate for the executive - and I say this without any false modesty -", he wrote several months later, "stems from an overestimation of my person." But he did promise to discuss the matter more fully with Kautsky later. ${ }^{2}$

This modesty and lack of political ambition were to prove a major obstacle throughout Haase's career. He failed, however, to convince Kautsky, and at this juncture Kautsky was a figure of great importance. Although often maligned, he remained the party's best known and most widely respected theoretician. He was also at the very center of party activity, constantly conversing with party leaders in Berlin and corresponding with those in the provinces. His endorsement could therefore be of very real significance.

More important, by 1911 Bebel had also concluded that Haase should be elevated to the leadership of the SPD. He had worked closely with Haase on a number of occasions ${ }^{3}$ and had evidently been impressed by his performance. Thus, the most eminent political leader and the most influential theoretician of the party were prepared to throw their weight behind the lawyer from distant Königsberg when the leadership crisis became acute. Within a few days after Singer's death both men appealed to Haase to abandon his reservations and become a candidate for the position now available. ${ }^{4}$ Once again, howev-

1 Karl Kautsky to Hugo Haase, February 14, 1909, Internationaal Instituut voor Sociale Geschiedenis (hereafter cited as IISG), Kautsky Nachlass (KC, No 429). Kautsky was at the time engaged in a conflict with the executive committee concerning its opposition to the continued publication of his very important pamphlet, Der Weg zur Macht. The executive committee based its objections in large measure on legal grounds, and Kautsky called upon Haase for technical advice. A significant part of the extensive correspondence relating to this matter, including the letter cited here, has been published in the International Review of Social History, XII (1967), No 3, pp. 432-477.

2 Hugo Haase to Karl Kautsky, June 5, 1909, IISG, Kautsky Nachlass (KD XII, No 10 ).

${ }^{8}$ One of the earliest and most important of these cooperative efforts took place in 1907 when the two men, along with Georg Vollmar, worked out the final text of the anti-war resolution passed by the International in that year. Ernst Haase, p. 17.

4 These letters are not available, but that they both had approached him is clear from Haase's letter to Kautsky of February 12, 1911, IISG, Kautsky Nachlass (KD XII, No 14). 
er, Haase hesitated. "For the moment I must refuse", he wrote Kautsky on February 12. "I have explained the grounds [for my decision] in a detailed letter to Bebel which you will no doubt see."1 But his refusal was not categorical, and the two leaders therefore continued to hope that it might be withdrawn.

In the same letter Haase suggested that his associate in Königsberg, Otto Braun, should replace Singer on the executive committee. Braun, who during the war was to become one of Haase's severest critics, was at this time considered a left-centrist and therefore appeared to be an appropriate substitute for Haase himself. Haase praised him as "very intelligent, consistently far-sighted, theoretically well-grounded, and gifted with journalistic talent".

This suggestion appealed, if not to Bebel and Kautsky, at least to many of the radicals who were eager to obtain a swift decision in their favor. The party's control commission, which was dominated by the left, had the legal right to fill vacancies in the executive committee between conventions. On February 12 Klara Zetkin, a left wing member of this commission, wrote Wilhelm Dittmann regarding the leadership crisis and asked him to indicate immediately whether he would be available as a candidate. ${ }^{3}$ Dittmann replied that he did not want to be considered, adding that in his view the situation should be resolved at the forthcoming convention in the fall. Furthermore, he felt that Haase, "for whom Bebel, who values him highly, will undoubtedly also intervene", would be the best man for the job.4 Despite Dittmann's advice, the control commission did act at once, electing Braun to replace Singer. They did this, however, without consulting the executive committee, which expressed such indignation that Braun withdrew his candidacy. ${ }^{5}$ A major criticism of Braun's candidacy came from Bebel who insisted that the new party chairman should be financially independent of the party as he and Singer had been. This view apparently was shared by many of those who feared the growing influence of the professional functionaries. ${ }^{6}$ Thus, Haase's suggestion was rejected but a few weeks after it was made. Moreover, Bebel's insistence that the new chairman must be financially independent further limited the number of possible candidates. Haase, as an eminently successful lawyer, could be expected to develop a new and profitable practice if he were to move to Berlin, thus satisfying this further requirement.

1 Haase to Kautsky, February 12, 1911.

2 Ibid.

3 Klara Zetkin to Wilhelm Dittmann, February 12, 1911, in Dittmann, pp. $322 f$.

4 Dittmann, pp. $322 f$.

5 Ibid., p. 323.

- Ibid. 
Dittmann's support was also not insignificant in the further development of Haase's candidacy. He immediately wrote to several members of the commission of seven which had played such a role in organizing the radicals at Magdeburg and which remained an active and potentially powerful force in internal party politics. Dittmann's suggestion that Haase be chosen to fill Singer's place met with general agreement. $\mathrm{He}$ also addressed a long letter to Haase urging him to become a candidate. ${ }^{1}$

The prospect of Haase's candidacy did not go unopposed. In a letter written to Kautsky in August, Bebel cautioned that he could not guarantee that Haase would be elected by a large majority. Yet, he added, "the more his candidacy is fought by the opposition, the more necessary it is that he accept, even if he is elected by a relatively small majority. In a fight one cannot set conditons for victory; one must take risks when the interests of the party require it."2

Bebel predicted that opposition could be expected from both the right and the left. Since Magdeburg, he wrote, Haase and the old radical warhorse, Georg Ledebour, were the potential candidates most hated by the revisionists. He thought that they might try to nominate Hermann Molkenbuhr, an older and relatively moderate member of the executive committee, for whom there was even some support in the executive committee itself. He had sought to head off this maneuver by writing to Molkenbuhr of his own objections to his candidacy. ${ }^{3}$

There was also a very real danger, Bebel continued, that the extreme left would put up its own candidate. He had heard the names of Ledebour and "even Dittmann" mentioned. If that were to occur, he speculated, the revisionist candidate would be certain to win, whoever he might be. Luxemburg had written him months before expressing her opposition to Haase and he had answered her appropriately. "It is possible", he concluded, "that if Rosa's and Klara's [Zetkin] intelligence and judgment are conquered by their passion and blind hate, this will be the result. I believe them capable of such stupidity."4

It is probable, however, that by August 5, when Bebel wrote this letter, the danger from the left was already long past. In June, Luxemburg had written Dittmann of a visit to Königsberg where she had discussed the leadership question with Haase at some length. This letter provides no evidence of active opposition on her part to Haase's candidacy. In it she noted that Bebel and many others were supporting

1 Dittmann, p. 323.

2 August Bebel to Karl Kautsky, August 5, 1911, IISG, Kautsky Nachlass (KD III, No 183).

3 Ibid.

4 Ibid. 
him and gave the impression that the matter would be resolved as far as she was concerned by Haase's own decision. ${ }^{1}$

In the meantime Haase continued to hesitate, although by this time he had retreated considerably from his earlier attitude. In her letter of June 17 to Dittmann, Luxemburg predicted that she would receive a definite answer from Haase within two weeks. ${ }^{2}$ On July 26 Dittmann finally received a long and generally positive reply to his earlier letter, but Haase still refused to commit himself. "It is not indifference which had caused me to delay my answer so long", he wrote,

"but indecisiveness regarding the question which you and a number of other comrades whom I regard highly have put to me. I confess that in March, after lengthy consideration, I rejected the candidacy for the executive committee which had been offered me, above all because I did not feel myself equal to the task. In the meantime, I have been urged from various quarters to abandon my refusal in the interests of the party, since it would be difficult to find a more suitable candidate and since my reservations are not well founded. This has led me to make repeated self-examinations, which have been made even more difficult by the fact that I am closely and happily tied by many bonds to Königsberg and that moving my home to Berlin will require the foundation of a new economic existence and will necessitate a complete change in my family's standard of living. Payment for my party activity is out of the question for me. Comrade Bebel advised me to become a lawyer in Berlin, and this way out could certainly be followed. I have not yet reached a decision, since I still must discuss the matter with a friend who will visit me next week."3

Apparently this friend was not negatively disposed toward Haase's candidacy, for the definitive answer was now not long in coming. When Bebel wrote to Kautsky on August 5, he still had no word from Königsberg, but on that same day Haase wrote to Kautsky, "I have

1 Rosa Luxemburg to Wilhelm Dittmann, June 17, 1911, Historical Archive of the SPD, Bonn, Nachlass Dittmann, "Photokopien vor 1918", No 106. A letter of July 28 is more specific on this question. In it, Luxemburg lists Haase's candidacy as one of those concerning which all of their "friends" were agreed. Rosa Luxemburg to Wilhelm Dittmann, July 28, 1911, Historical archive of the SPD, Bonn, Nachlass Dittmann, "Photokopien vor 1918", No 107.

a Rosa Luxemburg to Wilhelm Dittmann, June 17, 1911, Historical Archive of the SPD, Bonn, Nachlass Dittmann, "Photokopien vor 1918", No 106.

3 Hugo Haase to Wilhelm Dittmann, July 26, 1911, in Dittmann, pp. 324f. 
... succumbed to your and Bebel's attacks, however much I tried ... to defend myself against them." Even this reply, however, reflected a certain hesitation and lack of self-confidence. "I am, to be sure, convinced", he added, "that in this position I can be of some service to the entire party. Whether my energy will be sufficient or whether it will be too quickly consumed is a question about which I am in doubt." He appended a final plea that if Kautsky should discover some other candidate before the convention, he should intervene for him decisively. ${ }^{1}$

Kautsky's enthusiastic reply left little doubt that this request would lead to no practical result. "It is high time that a man of strong intelligence and energetic personality should finally once again come into the executive", he wrote. "In the past year it has become a universal laughing stock .... Bebel himself will have a completely different effect when he is no longer isolated.... You two united will give the entire executive a different complexion." The party secretaries were, despite their numerous weaknesses, generally "intelligent and useful" men, he added, and "under good leadership they will accomplish a great deal".2

The question of Haase's candidacy had finally been settled, but few thought that his election to the party chairmanship would completely solve the leadership problem. His supporters had long been agitating for an expansion of the executive committee as well as for a reorganization of the party structure aimed at insuring a closer relationship between the executive and the membership. Once again the commission of seven was mobilized, and again it was on the whole successful in achieving its goals. The orginal reluctance of the executive committee ${ }^{3}$ was overcome, and the convention voted to add two secretaries to it. The question of fundamental reorganization was referred to a study commission which was directed to report to the next convention. ${ }^{4}$ Moreover, Otto Braun and Phillipp Scheidemann, who were elected to fill the new secretaryships, were both at the time considered to stand left of center and apparently enjoyed the full support of the commission

1 Hugo Haase to Karl Kautsky, August 5, 1911, IISG, Kautsky Nachlass (KD XII, No 15).

2 Karl Kautsky to Hugo Haase, August 11, 1911, IISG, Kautsky Nachlass (KC, No 436).

s Substantial agreement among Haase's supporters concerning the desirability of enlarging the executive committee had already emerged at Magdeburg. But when the commission of seven met with the executive committee to discuss a proposal to this effect they found little enthusiasm for it. According to Dittmann, Ebert, fearing that Dittmann himself might be elected to the committee, claimed that he was by no means overloaded with work and that therefore no expansion was necessary. Dittmann, p. 298.

- Protokoll ...., 1911, pp. 160, 269f. 
of seven. ${ }^{1}$ Somewhat surprisingly, they also received the votes of the extreme right.

Haase's candidacy, on the other hand, was still considered too provocative to permit any compromise. Instead of bringing in a candidate from their own ranks, however, the revisionists shrewdly threw their weight behind Ebert. When he found his name on the list of candidates, Ebert himself immediately rose to declare that he would under no circumstances run for the chairmanship. He urged his supporters to vote rather for Haase. ${ }^{2}$ His plea was, however, answered by the revisionist labor union leader Carl Legien, who maintained that he could see no real reason for Ebert to refuse to become a candidate. He praised Ebert highly, noting his long experience in the executive committee and stressing that he had proved himself an effective mediator between the various factions within the party. He further pointed out that the convention had just appointed a committee to plan a reorganization of the leadership structure and that at such a time it was particularly important to elect men who had been actively engaged in the operation of that structure. He therefore urged all those who had intended to vote for Ebert not to be deterred from doing so by Ebert's attempt to withdraw his candidacy. ${ }^{3}$

Richard Lipinski, a member of the commission of seven, then plunged into this unusual debate. He did not praise Haase. Instead, he sought to counter Legien's argument regarding Ebert's importance to the forthcoming reorganization of the executive. The election of Ebert, he pointed out, would preempt the right of the reorganization committee to consider carefully whether the party should abandon its practice of electing only unpaid chairmen. ${ }^{4}$

Bebel too then entered the discussion, asserting that whether Legien could understand Ebert's grounds for refusing to become a candidate was of little importance. The decision, after all, lay with Ebert himself. He reported that Ebert's candidacy had been discussed by the executive committee and the control commission some time after Singer's death, but that even at that time Ebert had categorically refused to become a candidate. Moreover, Ebert himself had asked him to stress that his various interventions as a mediator had been conducted with the full support of his colleagues on the executive committee and therefore deserved no special commendation.

Concerning Haase's candidacy, Bebel observed that he himself had conducted the negotiations and that Haase had only consented to run

1 Dittmann, p. 336.

2 Protokoll ...., 1911, p. 371.

3 Ibid., pp. $371 f$.

4 Ibid., p. 372. 
after repeated efforts on his part to make clear the reasons which motivated the executive committee in supporting his candidacy. He noted further that Haase's move to Berlin would entail considerable financial and personal sacrifice on his part, but that despite this fact he had agreed to serve without salary. He answered the charge that a full-time chairman was needed by pointing out that, despite his legal practice, Haase would be able to visit the party offices daily, an arrangement which would constitute a considerable improvement over past practices. ${ }^{1}$

The revisionists were not yet satisfied. Karl Ulrich, of Offenbach, intervened to pinpoint more clearly the right wing's objections to Haase. Touching explicitly on "the purely personal side" of the question, he declared that he and a large number of other delegates had come to the conclusion that "in Ebert we would have a better, a more reliable chairman in view of the immense task of holding the party together as a unity". ${ }^{2}$ The reference was obviously to Haase's leadership of the left-center alliance, and Bebel felt called upon once more to rise to the defense of his friend. "I know what Ulrich is referring to with this remark", he asserted.

"In his place I would not have hesitated to express it openly here. I declare further that I find such reservations on the part of Ulrich and his friends completely natural, but I believe nevertheless that he draws the wrong conclusions from Haase's conduct at the Magdeburg convention. Everyone who knows him well knows that he is an unusually conciliatory man who would like nothing less than to provoke differences."

He added that the executive committee laid great weight on the fact that Haase was an excellent lawyer, whose advice would be extremely useful. In the last analysis, however, he recognized that those who had reservations about Haase would not now be convinced by his arguments and he knew that Haase's supporters would not abandon him. ${ }^{3}$ When the matter was brought to a vote, this prediction proved to be correct. Of the 393 votes cast, Haase received 283 and Ebert 102."

Haase's election represented a temporary return to the traditional leftcenter alliance against the right. ${ }^{5}$ But the revisionist demonstration

1 Protokoll ..., 1911, pp. 372f.

2 Ibid., p. 373.

3 Ibid., pp. $373 f$.

4 Ibid., p. 410.

5 Earlier in the convention Bebel had clashed with several of the leading representatives of the extreme left over Rosa Luxemburg's attacks on the 
against Haase was conducted with a kind of studied restraint usually foreign to such confrontations in the past. Dittmann viewed their opposition as directed primarily toward strengthening Ebert's position as the prospective successor to Bebel. ${ }^{1}$ In any case, the right wingers' relative moderation during the debate, combined with their support of Braun and Scheidemann, indicated that they were eager to avoid the kind of clash which might once more have cemented the left and center securely together. Unfortunately for Haase, they were largely successful in this. As Georg Kotowski has pointed out, the elections at the 1911 convention "were the last victory of the organized radicals". ${ }^{2}$

Haase thus assumed his party's highest office under inauspicious circumstances. Openly opposed by the growing right wing, his candidacy had been endorsed by many on the extreme left only because of that group's increasingly apparent isolation. He had, to be sure, received the support of the most important leaders of the center, but many of their colleagues presumably shared at least in part the reservations of the revisionists concerning the potential divisiveness of Haase's radicalism and only supported him out of loyalty to Bebel and because of the lack of a suitable alternative.

Moreover, Haase found it difficult to provide the strong leadership expected of him by Kautsky, even in spite of the fact that his position was reinforced early in 1912 by his election as co-chairman of the Reichstag delegation. His move to Berlin during the spring of 1912 was, of course, distracting. The establishment of a new law practice required both time and energy. ${ }^{3}$ Furthermore, although he was well acquainted with many national as well as local Berlin party leaders, the development of firm relationships of mutual trust and friendship with these men was of necessity a gradual process. The close cooperation between Haase and Bebel, which Kautsky had expected to be so fruitful, apparently did not develop. Writing to Victor Adler in May 1913, Kautsky reported that although Haase was a splendid person and worked very well in the executive committee, he was unfortunately unable to

executive committee for its handling of the Moroccan crisis of the previous summer. Ibid., pp. 204ff. Although the actual issues being debated could hardly be considered matters of principle, it was apparent that a serious break, which had long been brewing, had occurred in the left-center alliance which in the past had usually prevailed when crises arose at party conventions.

1 Dittmann, pp. 337f.

2 Georg Kotowski, Friedrich Ebert (Wiesbaden: Franz Steiner, 1963), I, p. 217.

3 His practice in Berlin was devoted largely to criminal cases and was never as successful, at least from the financial point of view, as it had been in Königsberg. Interview with Hans Haase and telephone interview with Kurt Boenheim, August, 1965. 
impress Bebel as Singer had. ${ }^{1}$ A month later Kautsky again praised Haase as "a good leader" in whom he placed great trust, but complained that he did not have enough authority to be generally effective. He blamed this situation on the fact that Haase was still too little known outside of his own circle and that he was neither a brilliant writer nor a moving speaker. ${ }^{2}$

Under these circumstances it is not surprising that Ebert continued to dominate much of the work of the executive. Haase, who could only spend an hour or two a day in the party offices and was at times called away from important meetings by his many other responsibilities, was in a weak position relative to the experienced full-time professional. ${ }^{3}$ Furthermore, Haase, as a theoretically oriented intellectual, found himself isolated in a committee dominated by pragmatic bureaucrats who naturally enjoyed a close rapport with Ebert. This situation was further exacerbated by Bebel's death during the summer of 1913 and Ebert's subsequent election to the co-chairmanship of the party with Haase. ${ }^{4}$ Ebert and Haase were apparently unable to work well together. Although there is little evidence to suggest that they differed fundamentally at this point on substantive issues, Kautsky reported to Adler that Ebert was jealous of his colleague and had complained that Haase was inclined to act too independently. ${ }^{5}$ Finally, Haase was hampered by his own serious reservations concerning his ability to succeed in his new position. He possessed little of the firm self-confidence that was so important an element in Bebel's character.

His position, in short, reflected the basic quandary confronting the party as a whole. Despite its growing numerical strength, so dramatically illustrated by its impressive victory in the 1912 Reichstag elections, the SPD was increasingly divided and confused about its mission. The very process by which Haase was selected indicates how unclear the party leaders were as to their ultimate goals. He was chosen as much for negative as for positive reasons. His candidacy represented in the last analysis the final gasp of a backward-looking centrism which was fast losing its viability.

1 Karl Kautsky to Victor Adler, May 21, 1913, in: Friedrich Adler, ed., Victor Adler: Briefwechsel mit August Bebel und Karl Kautsky (Vienna: Verlag der Wiener Volksbuchhandlung, 1954), pp. 564ff.

2 Karl Kautsky to Victor Adler, June 26, 1913, ibid., pp. 573f.

3 Philipp Scheidemann, Memoiren eines Sozialdemokraten (Dresden: Carl Reissner, 1928), I, pp. $81 f$.

4 Ebert was not, however, elected to the co-chairmanship of the Reichstag delegation until January 1916 when he replaced Haase after his resignation from that position.

s Karl Kautsky to Victor Adler, October 8, 1913, in: Adler, pp. 582ff. 
Moreover, if he were to have any success at all, Haase needed time to prove his leadership ability in the day-to-day affairs of the movement. But time was the all-important factor in this perspective, and sufficient time was not available. Within less than two years after his election the party found itself deprived of its one tried and universally respected leader, Bebel, who was also Haase's most effective source of support. A year later it was forced to confront, in the World War, the greatest challenge ever faced by Social Democracy, and that challenge inevitably forced its leaders to abandon the increasingly shaky tightrope of centrism. 